\title{
Sv. Ambróz. Výklad vyznania viery. O sviatostiach. O tajemstvách. Miloš Lichner - Róbert Horka (ed.).
} Starokrestanská knižnica 9. Trnava: Dobrá kniha, 2017, 308 s. ISBN 978-80-8191-065-4.

D A V I D V P Ř A D A

Jakkoli se české prostředí může pyšnit tradicí českých překladů Ambrožových děl sahající přinejmenším do dob humanismu, kdy roku 1601 Trojan Nigellus z Oskořína vydal svůj překlad Ambrožova spisu O dobru smrti, př́ležitostí, jak se dostat k překladům dalších Ambrožových děl, které by byly přístupné českému čtenáři, není mnoho. Mezi těmito spisy náleží zvláštní místo Ambrožovým mystagogickým katechezím, zvláště spisům De mysteriis a De sacramentis. $\mathrm{V}$ češtině je $\mathrm{v}$ úplnosti k dispozici pouze prvorepublikový překlad prvního ze spisů, vydaný Maurem Verzichem na pokračování v emauzském časopisu Pax. ${ }^{1}$ Další úryvky obou spisů jsou dostupné v rámci druhých čtení modlitby se čtením liturgie hodin, ${ }^{2}$ př́ípadně v rámci antologií. ${ }^{3} \mathrm{~S}$ ohledem na chystané vydání tří spisů Explanatio symboli, De mysteriis a De sacramentis je velice zajímavé vydání devátého svazku edice Starokrestanská knižnica, který obsahuje slovenský překlad těchto spisů společně s paralelním latinským textem. Autory překladu a úvodní studie jsou patrologové Miloš Lichner a Róbert Horka, jejichž hlavní patristickou specializací je život a dílo svatého Augustina, jenž je s Ambrožovou postavou emblematicky spjat křtem, který od Ambrože přijal. A nejen křtem: Augustin tyto či podobné katecheze na vlastní uši slyšel, když byl na Velikonoce roku 387 společně se synem Adeodatem a př́ítelem Alypiem v Miláně pokřtěn.

Překladu spisů do slovenštiny předchází rozsáhlá úvodní studie nadepsaná Svätý Ambróz a katechumenát (s. 6-122). Následuje latinský text, slovenský překlad a komentář $\mathrm{v}$ podobě poznámek třech zmiňovaných Ambrožových spisů, biblický rejstřík, rejstř́k starověkých autorů a sbírek a obsah. Po téměř povinném shrnutí života a pastýřské služby tohoto milánského biskupa se úvodní studie věnuje kontextu tří děl věnovaných křestní katechezi. Velmi patřičně nepomíjí, že jim předchází spis De Abraham, který zaznamenává podobu katecheze věnované kandidátům křtu (competentes) během posledních týdnů před Velikonocemi, kdy měli být pokřtěni (s. 37). Všímá si též vzájemného vztahu spisu De sacramentis, který zachycuje orální podobu mystagogických

1 Kniha o tajemstvích, př. Maurus Verzich. Pax 12 (1937), s. 138-141, 154-156, 173-175, 187-192.

2 Úryvky z Ambrožova spisu De mysteriis se čtou v průběhu 15. týdne v mezidobí.

3 Několik vět z obou spisů zahrnul J. J. Novák do své Patristické čitanky (Praha: Ústřední církevní nakladatelství 1988, s. 84-85), několik úryvků obsahuje také výbor Svatý Ambrož a tajemstvi Krista (Praha: Krystal OP 2015, s. 131-133, 135-137, 193); krátký úryvek De sacramentis lze nalézt také v časopise Na hlubinu 19 (1944-1945), s. 67-68. 
katechezí, a De mysteriis, jenž je Ambrožovým redakčním zpracováním těchto katechezí. Vzhledem k tomu, že velká část Ambrožova díla je redakčním zpracováním homilií věnovaných jednotlivým biblickým knihám, pronášených během eucharistické bohoslužby, je proto tento vztah zajímavý pro představu původní podoby Ambrožova kázání. ${ }^{4}$ Právě kázání tvoří základ Ambrožovy teologické metody, jíž se autoři pečlivě věnují v další části úvodní studie (s. 38-65). Ambrožova exegetická metoda, ve značné míře použitá i v jeho mystagogických spisech, je představena velmi stručně, autoři však vskutku pečlivě a dobře analyzují filologické a stylistické otázky spojené s jednotlivými spisy, které dovolují upozornit i na důležité okolnosti jejich vzniku. Lze jedině ocenit prostor věnovaný problematice autenticity Ambrožova autorství De sacramentis, které autoři uznávají (s. 52-57). Na základě rozboru šesti katechezí De sacramentis se dokonce odvažují na základě textu určit, jaká liturgická čtení se v milánské církvi na konci 4. století užívala (s. 51-52). Mám za to, že je $\mathrm{v}$ tomto případě potřeba velké opatrnosti, aby nedošlo $\mathrm{k}$ nepatřičnému zobecňování, nebot na základě jednoho literárního svědectví lze pouze stěží $\mathrm{s}$ jistotou určit, zda byl tento rozvrh čtení užit pouze $\mathrm{v}$ roce, kdy byly tyto katecheze zaznamenány, nebo zda již mohlo docházet k fixaci čtení na určité dny. Zároveň je otázkou, zda výklad modlitby Páně v sacr. 6 nutně předpokládá četbu Mt $6,9 \mathrm{nn}$. v sobotu velikonočního týdne, kdy byla tato katecheze pronesena - mezi křestní či předkřestní obřady mnoha církevních obcí tohoto období patří i předání modlitby Páně (traditio orationis), které obvykle předcházelo křestním obřadům; text modlitby Páně přitom patřil podobně jako krédo, význam křtu a eucharistie mezi „svátosti“, které se kandidátům křtu a nově pokřtěným předávaly $\mathrm{v}$ rámci tzv. disciplina arcani, a výklad otčenáše $\mathrm{v}$ sacr. 6 má spíše tuto spojitost.

Další důležitá kapitola úvodní studie se věnuje rekonstrukci katechumenátu v antické církvi a zvláště v Miláně koncem 4. století, vycházející především z Ambrožových děl s popisem jednotlivých obřadů velikonoční noci, počínaje obřadem efetha, přes umývání nohou, typické pro Milán, až po společné první slavení eucharistie s ostatními věřícími (s. 65-104). Úvodní studie končí poměrně nečekaně kapitolkou věnovanou postavě Melchizedecha, která sice hraje $\mathbf{v}$ katechezích dủležitou úlohu, ale čtenáři nemusí být zcela jasné, proč se rozbor mystagogických katechezí náhle uzavírá právě zde (s. 104-107). Celkově je představení Ambrože a jeho mystagogické teologie velmi zdařilé a čtenáři může posloužit jako výborné uvedení do myšlení tohoto církevního otce.

Jako čtenář, pro nějž slovenština není mateřským jazykem, mohu jen těžko Lichnerův a Horkův překlad hodnotit. Považuji jej však za srozumitelný a stručné poznámky, jež doplňují text, mohou čtenáři pomoci pochopit smysl obtížnějších míst, která potřebují osvětlit jejich historicko-teologický kontext. Nejen slovenským přátelům raněkřestanské literatury lze proto tento překlad

4 K tématu viz např. David Vopřada. Planus atque suavissimus doctor. Milánský biskup Ambrož jako kazatel. Salve. Revue pro teologii a duchovní život 18, 1 (2008), s. 17-32. 
zásadních děl latinské patristiky a dějin teologie doporučit, ale i autorům popřát, aby ve spolupráci s dalšími, kteří se podílejí na vydávání Starokrestaské knižnice, zdárně pokračovali v takto kvalitním zpř́stupňování patristických děl současným čtenářům, kteří v nich mohou hledat povzbuzení, poučení, potravu a zdroj pro obnovu vlastního života i života celé církve.

doi: 10.14712/23363398.2018.24 